\title{
СУЧАСНИЙ СТАН ТА ТЕНДЕНЦІї РОЗВИТКУ ВІТЧИЗНЯНОГО СВИНАРСТВА
}

\author{
Лихач Вадим Ярославович \\ доктор сільськогосподарських наук, доцент \\ Національний університет біоресурсів і природокористування України \\ ORCID: 0000-0002-9150-6730 \\ E-mail: vylykhach80@nubip.edu.ua \\ Лихач Анна Василівна \\ доктор сільськогосподарських наук, доцент \\ Національний університет біоресурсів і природокористування України \\ ORCID: 0000-0002-0472-6162 \\ E-mail: avlykhach@nubip.edu.ua \\ Фаустов ${ }^{1}$ Ростислав Вікторович \\ аспірант кафедри технології виробництва продукції тваринництва \\ Миколаївський національний аграрний університет \\ ORCID: 0000-0003-2732-4032 \\ E-mail: svalker2013@gmail.com \\ Кучер Олена Олександрівна \\ кандидат сільськогосподарських наук, доцент \\ Миколаївський національний університет ім. B.О. Сухомлинського \\ ORCID: 0000-0002-9963-6855 \\ E-mail: hrizantema84.84@gmail.com
}

\begin{abstract}
Свинарство є важливою галуззю національної економіки, що забезпечує населення продуктами харчування, переробну промисловість - сировиною, а також сприяє створенню необхідних державних резервів тваринницької продукції, інтенсивному використанню земельних ресурсів. Проте, фактичний стан галузі нині не відповідає її потенційним можливостям і потребує додаткової уваги з боку держави, практиків, науковців. Отже, метою досліджень було оцінити сучасний стан та визначити тенденції розвитку вітчизняного свинарства, як стратегічно важливої галузі у загальній структурі сільськогосподарського виробництва України. Чисельність свиней в Україні з 2009 по 2020 рр. змінювалася порізному, до основних причин суттєвого скорочення поголів'я свиней в країні слід віднести: диспаритет цін на сільськогосподарську та промислову продукцію; зростання цін на корми; неспроможність більшості вітчизняних товаровиробників застосовувати новітні технології утримання та відгодівлі свиней; ліквідація спеціалізованих свинарських господарств (до 300 свиноматок); насичення вітчизняного ринку сировиною іноземного виробництва; скорочення обсягів державної підтримки; ускладнення епізоотологічної ситуації (АЧС); скрутне економічне положення пересічних українців. Впродовж проаналізованих років, найменше було вироблено свинини за 2020 рік, де основною причиною цього явища були несприятливі погодні умови, світова та державна економічна криза, спричинена масовою пандемією коронавірусу COVID-19. Цей показник свідчить, що більше ніж 70\% свинини в Україні виробляється екстенсивно, тобто при тому ж поголів"ї свиней в країнах ЄС, Канаді, Бразилії, США буде вироблено, і виробляється на 70\% свинини більше. На сучасному етапі в Україні ставиться завдання радикально відродити галузь свинарства та перевести їі на індустріальну технологію, а також добитися того, щоб вона могла давати дешеву, високоякісну та конкурентоспроможну продукцію. Для цього наша країна має необхідний племінний генофонд та племінну базу свиней, володіє родючими землями для формування відповідної кормової бази, а також висококваліфрікованим потенціалом науковців і виробничників для раціонального ведення галузі свинарства. Перспективами розвитку галузі свинарства є: збільшення кількості поголів'я свиней в усіх категорій господарств країни до 11678,9 тис. голів; зниження конверсії корму до 2,5-3,2 ке, зниження віку забою тварин до 165-170 днів; отримання від свиноматки за рік 25-28 «ділових» поросят; збереження локальних вітчизняних порід.
\end{abstract}

Ключові слова: свинарство, поголів'я, порода, ринок свинини, сільськогосподарські підприємства, господарства населення, попит, імпорт, цінова ситуація.

DOI: https://doi.org/10.32845/bsnau.Ivst.2021.1.10

Рівень життя населення тісно пов'язаний із розвитком галузей тваринництва, частка якого в структурі продовольства становить понад 45\%, зокрема галузь свинарства займає близько $40 \%$, у забезпечені населення м'ясною продукцією. Вартість свинини знаходиться на третьому місці після ягнятини та яловичини, а за своїми поживними й кулі-

${ }^{1}$ Науковий керівник - доктор с.-г. наук, доцент Лихач В.Я. нарними перевагами свинині належить перше місце 3-поміж іншої м'ясної продукції $[7,9,13,21,22]$. Свинарство $є$ важливою галуззю національної економіки, яка забезпечує населення продуктами харчування, переробну промисловість - сировиною, а також сприяє створенню необхідних державних резервів тваринницької продукції, інтенсивному використанню земельних ресурсів. Проте, фрактичний стан галузі нині не відповідає її потенційним можливостям і пот- 
ребує додаткової уваги з боку держави, практиків, науковців. Необхідною умовою подальшого розвитку свинарства в Україні є прискорений перехід на виробництво конкурентоспроможної м'ясної свинини. Інтенсивне виробництво продукції свинарства висуває нові підвищені вимоги до технологічних особливостей ведення галузі $[10,16,17,29]$.

Здоров'я населення України та, власне, продовольча безпека, в значній мірі пов'язані із рівнем виробництва та споживанням білків тваринного походження, основним джерелом якого є м'ясо і м'ясопродукти. Особливу гостроту ця проблема набула у зв'язку із суттєвим спадом виробництва м'яса внаслідок непослідовних ринкових реформ в Україні, критичним станом сільськогосподарських підприємств, які є сировинною базою розвитку переробної й харчової промисловості, погіршенням матеріального становища сільських трудівників [1, 9, 21, 22].

Рішення проблеми зростання виробництва м'яса та підвищення рівня забезпечення населення м'ясною продукцією, значною мірою, залежать від розвитку свинарства, особливості якого дають змогу в найкоротші строки забезпечити збільшення поголів'я свиней і досягти необхідного обсягу виробництва м'яса. За своєю господарською значущістю свинарство, як національно ідентична галузь в Україні, традиційно посідає перше місце серед інших галузей тваринництва. Адже у кризових ситуаціях саме воно нерідко ставало головним джерелом швидкого нарощування обсягів виробництва м'яса $[4,8,13,14,29]$. Крім того, свинарство $€$ однією з ключових галузей, що забезпечує Україну м'ясо-сальною продукцією. Однак, в Україні внаслідок кризи в аграрному секторі виробництво свинини значно зменшилося, проте зазначена галузь надалі залишається однією 3 перспективних у формуванні продовольчої безпеки держави, забезпеченні внутрішнього попиту на м'ясну продукцію вітчизняного виробництва $[14,17,20,22,29]$.

Мета досліджень - оцінити сучасний стан та визначити тенденції розвитку вітчизняного свинарства, як стратегічно важливої галузі у загальній структурі сільськогосподарського виробництва України.

Матеріали та методи досліджень. Враховані та проаналізовані дані щодо стану галузі свинарства за період 2009-2020 років. За узагальнення тенденцій та перспектив розвитку свинарства були використані методи синтезу та аналізу, метод порівняння.

Результати досліджень. На сучасному етапі в Україні виробництвом свинини займаються в основному дві категорії товаровиробників: присадибні господарства населення і сільськогосподарські підприємства. При цьому в присадибних господарствах утримується біля 50\% свинопоголів'я від загальної кількості тварин [2, 7, 12, 15, 22].

Щорічна динаміка поголів'я свиней залежно від категорії господарства наведена на рис. 1.

Спостерігаючи за щорічною динамікою чисельності поголів'я свиней у різних категоріях господарств варто зазначити, що станом на 2009 рік в усіх категоріях господарств утримують 6526 тис. голів свиней, а в 2010 році - 7577 тис. голів, що на $16,1 \%$ більше попереднього року $[6,10,12,16$, 22, 30]. Такий числовий ряд переконливо свідчить про нарощування свинопоголів'я в Україні.

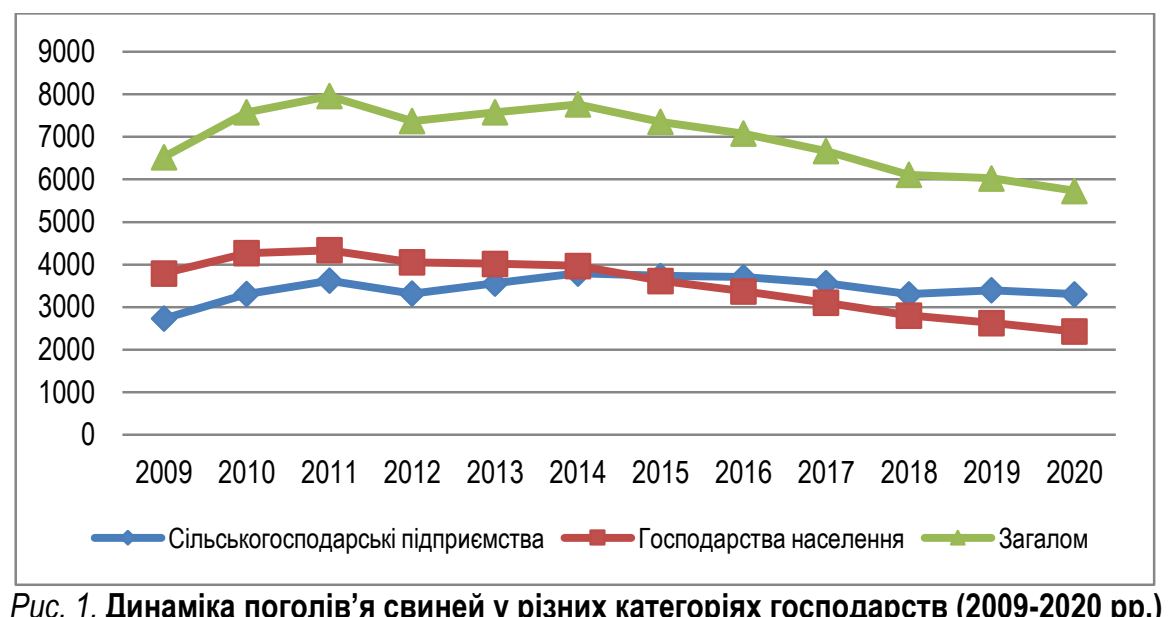

Puc. 1. Динаміка поголів'я свиней у різних категоріях господарств (2009-2020 рр.)

Варто відзначити, що у 2011 році основними виробниками свинини в Україні стали присадибні господарства, на частку яких припадало 54,5\% (4335 тис. голів). Збільшення кількості свиней в присадибних господарствах було передусім вимушеною об'єктивною реакцією населення на загальний кризовий стан економіки в цілому і зменшення чисельності свиней в сільськогосподарських підприємствах [12, 21, 27]. Станом на 2012 рік, який виявився неоднозначним для галузі тваринництва і свинарства зокрема. Впродовж року спостерігалися як стимулюючі фактори, так і складнощі. До сприятливих факторів можна віднести: позитивні цінові тенденції на ринку забійних свиней, повне забезпечення кормами за рахунок високих врожаїв та низьких цін на них. Серед головних труднощів слід виділити відміну державної дотаційної підтримки і збільшення обсягів поставок імпорт- ної свинини. Все це призвело до того, що загальна чисельність свинопоголів'я мала наступний розподіл за категоріями господарств: 45,1\% свиней (3319 тис. гол.) утримувалося сільськогосподарськими підприємствами, а решта $54,9 \%$ (4054 тис. гол.) - присадибними господарствами [12].

Помітна тенденція щодо зниження поголів'я свиней у присадибних господарствах, що, на нашу думку, має чітку сезонність (див. рис. 1.). Зокрема, скорочення свинопоголів'я відбувається під час новорічних, різдвяних та великодніх свят, що пояснюється зростанням споживання м'яса під час масових святкувань. Стосовно сільськогосподарських підприємств, то чисельність поголів'я свиней, які тут утримуються має не таку різку амплітуду коливань.

Виробничі показники 2013 року стали відчутно кращими. Додатковим стимулом розвитку галузі свинарства в 
цьому році стало тимчасове обмеження імпортних поставок бразильського м'яса, яке, як відомо, домінує з-поміж усього завезеного. В свою чергу, цінова ситуація була сприятливою для товаровиробників, а збільшення внутрішнього споживання та скорочення загального імпорту позитивно позначилося на стані галузі свинарства. У розрізі категорій необхідно відмітити, що у сільськогосподарських підприємствах утримували 3557 тис. гол. свиней, що майже на 10\% більше аналогічного показнику 2012 року [3, 6, 8, 12, 22, 24]. Це підтверджує той факт, що загальне зростання в галузі відбувається за рахунок нарощування потужностей промисловими виробниками свинини. Відносно присадибників, то тут кількість свинопоголів'я залишалася майже незмінною.

У 2014 році спостерігались тенденції щодо зниження кількості поголів'я свиней у присадибних, i, навпаки, збільшення у сільськогосподарських господарствах у порівнянні 3 2013 роком на майже $1 \%$ і $6 \%$ відповідно $[6,12,13,27]$. Зберегти позитивну динаміку, порівняно з минулим роком, змогли лише шість областей України - Івано-Франківська, Київська, Львівська, Тернопільська, Харківська та Хмельницька.

Слід відзначити, що 2015 рік є безпрецедентним для українського свинарства, адже чисельність свиней у сільськогосподарських підприємствах більша (3733 тис. гол.), ніж у присадибному секторі (3618 тис. гол.). Це свідчить, що промислове свинарство нарощує виробничі потужності. Ситуацію, що склалася у присадибних господарствах можливо пояснити за рахунок складної політичної ситуації в країні, де найбільших втрат зазнало свинопоголів'я господарств населення на Донеччині та Луганщині: на 20\% та 30\% менше, ніж у 2014 році, відповідно [6, 22].

Вартий уваги той факт, що впродовж другого кварталу спостерігається позитивна динаміка чисельності промислового поголів'я. Проте у липні незначне скорочення свинопоголів'я на сільськогосподарських підприємствах відбулося у десяти областях i, напевно, триватиме ще деякий час. Причиною цієї обставини є поширення африканської чуми свиней (АЧС), внаслідок якої свиней ліквідують не тільки ті господарства, що опинилися у зоні ризику поширення цієї хвороби, але й ті, хто не може в силу масштабу посилити рівень біобезпеки до потрібного [4, 6-8, 22, 30].

Зниження кількості свинопоголів'я у промисловому секторі пояснюється тим, що малі підприємства (до 300 свиноматок) через низьку ефективність, не витримали тиску економічних обставин, які склалися в Україні і, як наслідок, припинили свою роботу.

У 2016-2020 році спостерігається тенденція до збільшення поголів'я свиней у сільськогосподарських підприємствах у порівнянні із господарствами населення. Проте, варто відзначити фракт стрімкого зниження поголів'я свиней незалежно від категорії господарств в період з 2016 по 2020 pp., де головною причиною такого негативного явища $€$ поширення африканської чуми свиней (АЧС).

Отже, надаючи розподіл свинопоголів'я за різними категоріями господарств, повідомляємо, що чисельність свиней в Україні з 2009 по 2020 рр. змінювалася по-різному, рис. 2. Дані діаграми переконливо свідчать, що найсприятливішим роком для збільшення кількості свиней в Україні був 2011.

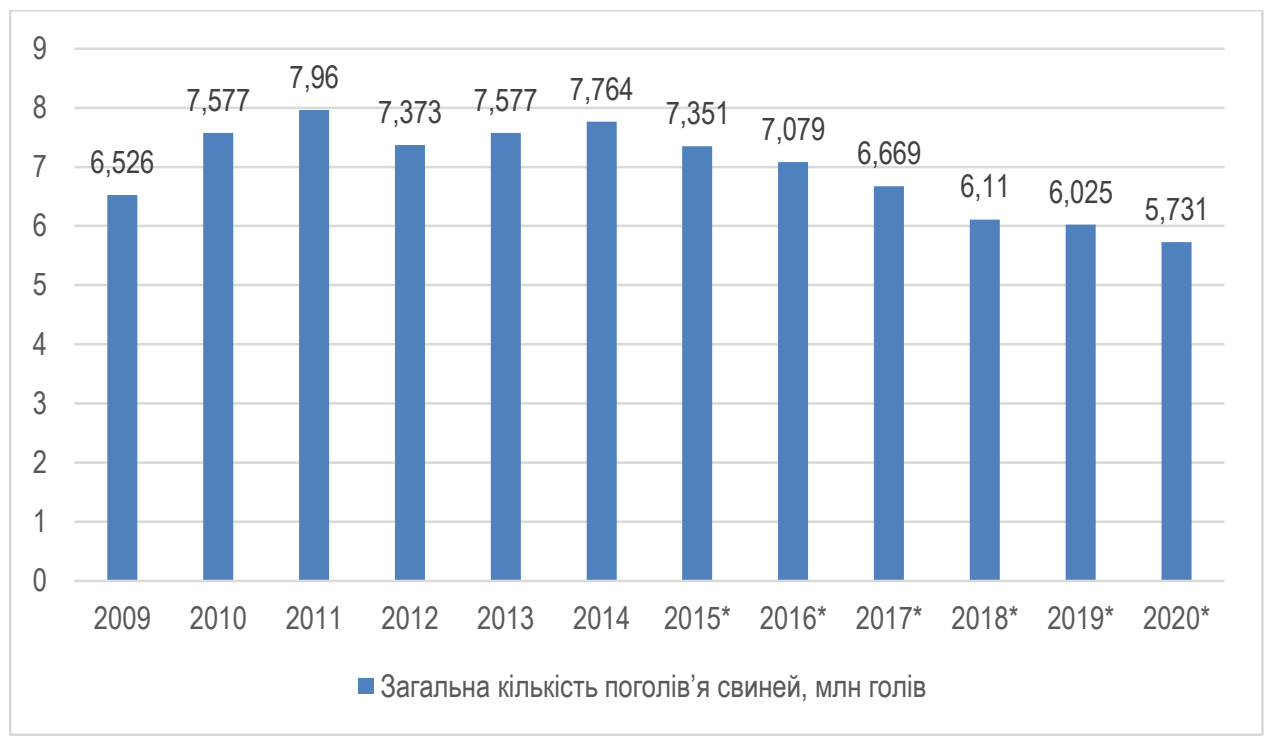

Puc. 2. Динаміка поголів'я свиней в Україні, станом на 01 січня (2009-2020 рр.)

Дані наведено без урахування тимчасово окупованої території Автономної Республіки Крим, м. Севастополя та частини тимчасово окупованих територій у Донецькій та Луганській областях.

До основних причин суттєвого скорочення поголів'я свиней в країні, на нашу думку, слід віднести: диспаритет цін на сільськогосподарську та промислову продукцію; зростання цін на корми; неспроможність більшості вітчизняних товаровиробників застосовувати новітні технології утримання та відгодівлі свиней; ліквідація спеціалізованих свинарських господарств (до 300 свиноматок); насичення вітчизняного ринку сировиною іноземного виробництва; скорочення обсягів державної підтримки; ускладнення епізоотологічної ситу- ації (АЧС); скрутне економічне положення пересічних українців $[4,7,18,21,22]$.

Натепер в Україні розводять понад десяток різних порід свиней вітчизняного та зарубіжного походження, а також спеціалізованих типів і ліній. В країні створено відповідну племінну базу, яка $є$ надбанням держави й багаторічної праці вчених-селекціонерів разом зі спеціалістами та керівниками господарств [21, 23].

Стосовно породного складу свиней в Україні, варто 
зазначити, що традиційною є для України галузь свинарства, коли класичними комерційними породами залишаються велика біла - 183910 голів, а це у відсотковому співвідно- шенні становить майже $52 \%$ та ландрас - 132334 голови, що становить $37 \%$ (табл. 1) [16, 21-23].

Породний склад племінного поголів'я свиней станом на 01.01.2018 року

\begin{tabular}{|l|c|c|c|}
\hline \multicolumn{1}{|c|}{ Порода } & $\begin{array}{c}\text { Усього } \\
\text { голів }\end{array}$ & Кількість голів, \% & У т.ч. основних свиноматок, гол. \\
\hline Велика біла & 183910 & 51,9 & 13551 \\
\hline Ландрас & 132334 & 37,3 & 15518 \\
\hline Українська м'ясна & 10033 & 2,8 & 601 \\
\hline Потавська м'ясна & 8980 & 2,5 & 463 \\
\hline Червона білопояса & 6444 & 1,8 & 309 \\
\hline Дюрок & 3767 & 1,1 & 255 \\
\hline П'єтрен & 2581 & 0,7 & 171 \\
\hline Миргородська & 2056 & 0,6 & 283 \\
\hline Велика біла (англійської селекції) & 1615 & 0,5 & 215 \\
\hline Українська степова біла & 1495 & 0,4 & 100 \\
\hline Велика чорна & 1076 & 0,3 & 21 \\
\hline Уельська & 313 & 0,05 & 32437 \\
\hline Українська степова ряба & 92 & 0,05 & 100 \\
\hline Усього & 354696 & 100 & \\
\hline
\end{tabular}

Трійку лідерів замикає вітчизняна порода - українська м'ясна порода, загальною кількістю поголів'я 10033 голови із 801 основною свиноматкою, де із загальної кількості на іï частку припадає майже $3 \%$.

Однак важливим $€$ показник не поголів'я, а обсягів виробленого та реалізованого м'яса. Так, у 2020 році в Україні вироблено 324,5 тис. тон приросту живої ваги, що майже на 38,3\% менше за обсяг вирощеної свинини 2015 року, рис. 3.

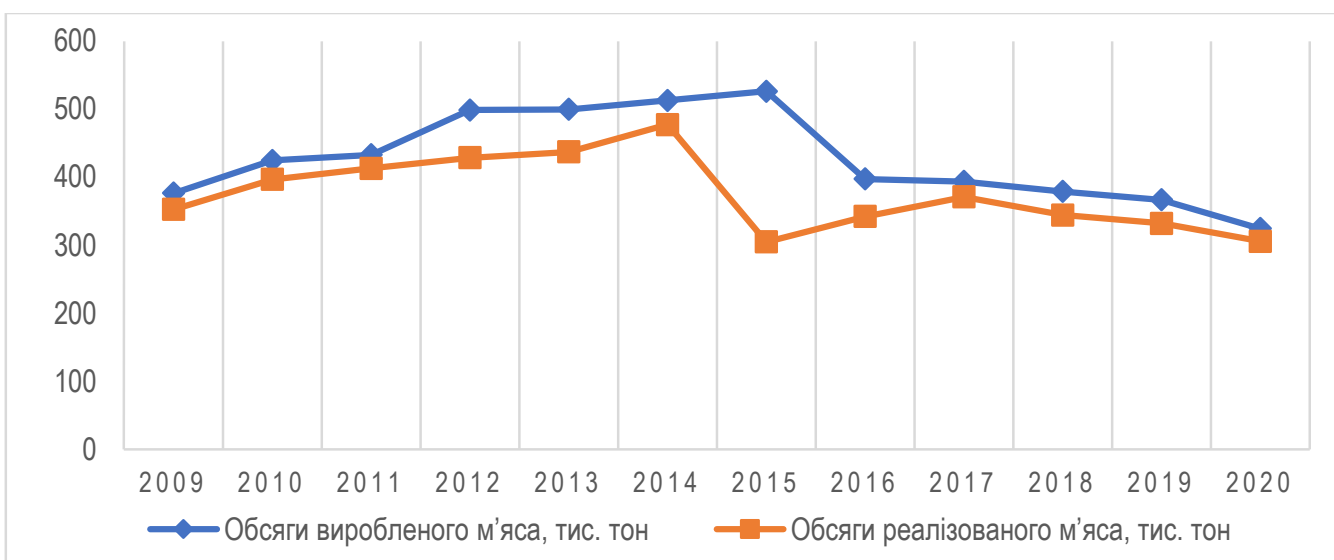

Puc. 3. Динаміка обсягів виробництва та реалізації м'яса свиней (2009-2020 рр.)

(дані наведено без урахування тимчасово окупованої території Автономної Республіки Крим, м. Севастополя та частини тимчасово окупованих територій у Донецькій та Луганській областях).

Констатуємо, що впродовж проаналізованих років, найменше було вироблено свинини за рік у 2020 році, де основною причиною цього явища були несприятливі погодні умови, світова та державна економічна криза, спричинена масовою пандемією коронавірусу COVID-19. Цей показник свідчить, що більше ніж 70\% свинини в Україні виробляється екстенсивно, тобто при тому ж поголів"ї свиней в країнах ЄС, Канаді, Бразилії, США буде вироблено, і виробляється на $70 \%$ свинини більше $[4,22,24,30]$.

Половина отриманого приросту живої ваги свиней припадає на п'ятірку областей, де активно розвивається галузь свинарства. Однак, як зазначає О. Бондарська [6, 22], що лише у Київській та Івано-Франківській областях зберіглася позитивна динаміка, тоді як у Донецькій, Дніпровській та Полтавській - обсяги вирощування свиней дещо скоротилися.

Проте збільшення приростів живої ваги отримали за рахунок свиногосподарств Рівненської області - на $32 \%$, у
Тернопільській - на 30\%, а на Житомирщині - на 20\%. У середньому за аналізований період промислове поголів'я нарощувало по 483 г на добу [12, 22, 24].

Що стосується показнику обсягу реалізації свинини, то слід відмітити, що найбільший показник зафріксований у 2014 році і становить 477,5 тис. тон свинини. Протягом 20112013 рр. в країні реалізовано приблизно однакову кількість свинини - в межах 412,9-437,1 тис. тон. Майже 93\% отриманих приростів, а саме 304,8 тис. тон, реалізували на забій у 2015 році. Основну стримуючу роль зіграли підприємства Донеччини та Полтавщини, які зменшили реалізацію на забій на 5,8 та 3 тис. тон відповідно, порівняно з 2014 роком. Варто відзначити і ту обставину, що з 2014 по 2020 роки обсяги реалізації свинини мали тенденцію до зниження і станом на 2020 р. цей показник становив - 305,7 тис. тон. Разючого падіння зазнали обсяги реалізації на забій підприємствами Луганщини та Чернівецькій області, де цей показник зменшився вдвічі та на третину відповідно $[6,8,12,13$, 
22].

3 огляду на цінову ситуацію в період з 2009-2020 років, повідомляємо, що закупівельні ціни на свиней у живій вазі постійно зростали, рис. 4. Отже, станом на 2010 рік закупівельні ціни на свиней м'ясного типу зупинилися на позначці 18,5 грн/кг. Це на 2,3\% вище порівняно із ціною 2009 року, що свідчить про скорочення імпорту та відповідно зростання попиту на вітчизняну свинину. Ціни ж на м'ясосальних свиней (II категорії) трималися на рівні 16,5 грн/кг
[2, 4, 11, 12, 22, 25]. У 2011 році спостерігалося відчутне скорочення обсягів імпорту свинини, що відбилося на внутрішніх цінах на тварин. Так, на таке скорочення імпорту м'яса вітчизняний ринок відреагував цілком логічно: для підтримки обсягів виробництва, що, у свою чергу, викликало ріст цін і на готову продукцію. Так, закупівельна ціна на свиней । категорії підвищилася на $5 \%$ і становила 19,45 грн/кг, проте ціна на свиней II категорії здешевіла до позначки 15,5 грн/кг.

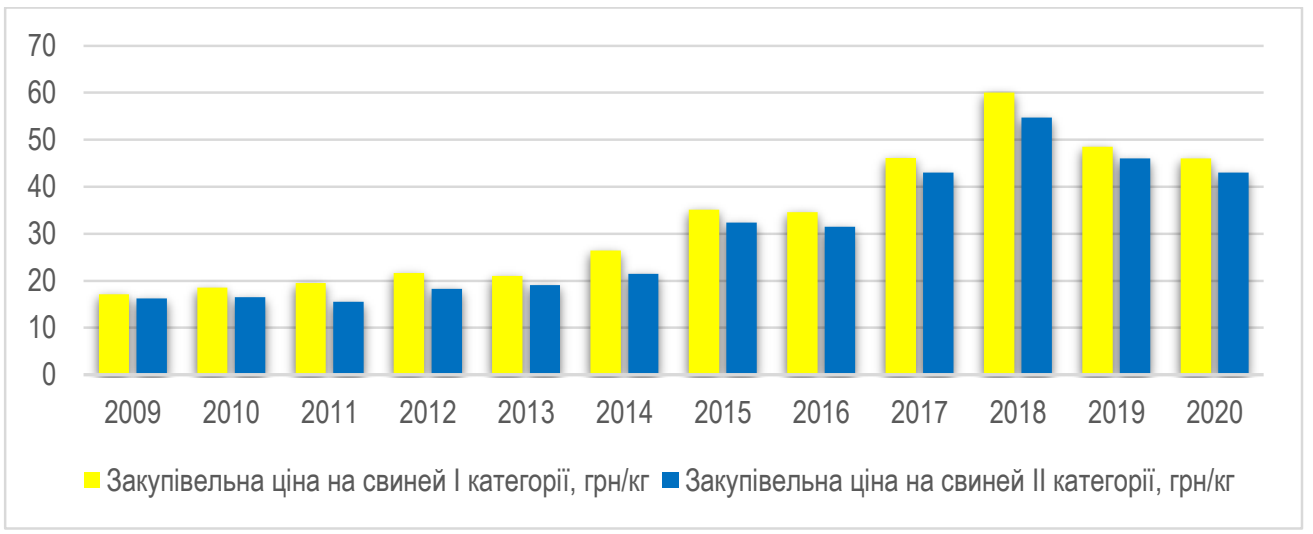

Puc. 4. Динаміка закупівельних цін на свиней залежно від категорії, грн/кг

Середньорічні закупівельні ціни на м'ясних свиней у 2012 році складали 21,6 грн/кг, що на 11\% були дорожчими, ніж у минулому році. Хоча наприкінці грудня цього ж року мінімальна ціна становила 18,8 грн/кг живої ваги. Така тенденція до падіння ціни була пов'язана із низькою купівельною спроможністю населення, значною часткою імпортної свинини на ринку та демпінговою політикою найкрупніших виробників свинини. Що стосується свиней II категорії, то середньорічна ціна на них теж зросла: 18,3 грн/кг у 2012 році порівняно з 15,5 грн/кг у 2011 році. Рік 2013 був достатньо динамічним щодо цінових тенденцій на ринку живих свиней $[5,6,18,22]$. Окрім сезонності, важливими ціноутворюючими чинниками були погодні умови, імпортні поставки та ціни на світовому ринку. Однак, порівняно з 2012 роком, ціни на свиней I категорії були у вужчому діапазоні - 21,00 грн/кг.

На ринку закупівельних цін на свинину 2014, 2015 років ціна знову відновила рух на підвищення відповідно на 5-7 грн/кг і 15-17 грн/кг. Таке підвищення пов'язане із зниженням споживчої активності, скорочення кількості сільськогосподарських підприємств та підвищення ціни на кормові культури.

Зокрема, закупівельні ціни 2016 року на свиней забійних кондицій першої категорії були відчутно нижчими ніж торік через дуже слабку експортну активність, порівняно 3 2015-м та доволі млявий внутрішній попит, який більшу частину року не міг втримати ціни на рівні минулого року. Це також мало вплив на роздрібну ціну свинини, зменшивши ії середньорічний рівень на 2-5\%, а також суттєво «згладивши» іï сплески. А тому, констатуємо, що вартість закупівельних цін свиней I категорії становила 34,6 грн/кг, a II категорії $-31,5$ грн/кг.

У 2017 році констатуємо чергове підвищення цін на живець I категорії - 46,1 грн/кг, II - 43,0 грн/кг відповідно. У 2018 році на ринку свинини живою вагою намітилася висхідна динаміка закупівельних цін. Власне, такий підйом був викликаний активнішою заготівлею сировини м'ясопереробними підприємствами. Згодом це переросло у поступовий висхідний рух цін у передноворічний період. Тому, закупівельні ціни на свинину I категорії підскочили до позначки 60,0 грн/кг, a II - 54,7 грн/кг. Загалом зміна цін на свинину живою вагою залежить від цілої низки чинників: споживча активність, на яку впливають як сезонні коливання попиту, так і купівельна спроможність; сезонні коливання попиту/пропозиції живця; очікування гравців ринку; жвавість зовнішньої торгівлі; цінова динаміка на ринку ресурсів (корми, ветпрепарати, енергоносії та електроенергія тощо), яка в свою чергу залежить від коливання валютних курсів.

Стосовно 2019 р. і 2020 р. відзначаємо, що ціни на живець дещо знизилися у порівнянні з 2018 роком й становили 48,5 і 46,0 на свинину I категорії, 46,2 та 43,0 - на свинину II категорії відповідно.

Варто також пам'ятати, що в Україні свинина не найдорожча у закупівлі. Так, у країнах Європи ціни на свинину незначно нижчі або співставні з українськими, в РФ кілограм живця коштує 44 грн, в Італії - майже 45 грн/кг, у Китаї понад 60 грн/кг.

Таким чином, ефективність свинарства залежить від генетики, технології вирощування і годівлі, здоров'я тварин й кормів. В структурі собівартості свинини найбільшу частку складають витрати на корми (до 70-80\%). Нестача поживних речовин, особливо білка, а також амінокислот, вітамінів, макро- та мікроелементів, спричиняє зниження приростів, збільшення строків відгодівлі, перевитрати кормів та, як наслідок, собівартість свинини, що вища, ніж в країнах ЄС. Зважаючи на показники виробництва свинини на даний час, виникає запитання, чи правильно ми використовуємо той ресурс, який у нас $€$ ? За минулий рік Україна виробила зернових культур 3\% від загальносвітового обсягу (так само як Бразилія і Канада), а свинини лише 0,5\% (Бразилія 3\%, Канада 2\%) $[4,6,10,11,12,16,22,26,28]$.

3 огляду на вищевказане, пропонуємо розглянути динаміку цін на кормові культури для годівлі свиней, табли- 
ця 2.

3 початком нового 2010 року в Україні ціни на зерно зростали швидкими темпами у зв'язку з невисокою врожайністю культур, а також реагуючи на стан світового ринку. За даними операторів зернового ринку, ціна на пшеницю коливалася в межах 1570-1650 грн/т., на ячмінь - 1450-1500 грн/т., кукурудза знаходилась в тих же цінових межах 1600-1650 грн/т. [6, 7, 12, 16, 22]. В свою чергу, середньовиважені ціни по Україні на шрот соняшниковий становили 1750 грн/т., що на 10,8\% вище у порівнянні 3 попереднім 2009 роком.

Тенденція до підвищення ціни спостерігалася також для макухи та шроту соєвого, яка зупинилася на позначках
3200 грн/т й 3900 грн/т. відповідно.

Підвищення цін на кормові засоби в Україні має стабільну тенденцію і на 2011-2020 роки, що пов'язане із невисокою врожайність, недостатньою кількістю потужностей для зберігання, зменшенням активності закупівлі на українському ринку тощо. Тому, констатуємо, що за даними Держкомстату України $[1,3,12,22]$ станом на 2020 рік ціна пшениці за тону зросла до 6225 грн, ячменю - 5420 грн, кукурудзи 4840 грн, шроту соняшникового - 10400 грн, макухи соєвої 12150 грн і шроту соєвого - 14500 грн, що становить на $2,1 \%,-3,2 \%, 4,1 \%, 0,5 \%, 1,7 \%$ і 3,6\% більше порівняно 3 минулим 2019 роком, відповідно.

Динаміка цін на кормові засоби в Україні

Таблиия 2

\begin{tabular}{|c|c|c|c|c|c|c|}
\hline \multirow{2}{*}{ Роки } & \multicolumn{7}{|c|}{ Середня вартість кормових культур, грн/т } \\
\cline { 2 - 7 } & пшениця & ячмінь & кукурудза & $\begin{array}{c}\text { шрот } \\
\text { соняшниковий }\end{array}$ & $\begin{array}{c}\text { макуха } \\
\text { соєва }\end{array}$ & $\begin{array}{c}\text { шрот } \\
\text { соєвий }\end{array}$ \\
\hline 2009 & 1400 & 1200 & 1500 & 1580 & 3120 & 3500 \\
\hline 2010 & 1570 & 1500 & 1650 & 1750 & 3200 & 3900 \\
\hline 2011 & 1700 & 1700 & 2000 & 2200 & 3700 & 4200 \\
\hline 2012 & 1800 & 1790 & 1400 & 2350 & 3750 & 4600 \\
\hline 2013 & 2500 & 2300 & 2500 & 3200 & 4400 & 5200 \\
\hline 2014 & 3100 & 2750 & 2900 & 3900 & 5300 & 6700 \\
\hline 2015 & 3400 & 3300 & 3000 & 5300 & 8100 & 10500 \\
\hline 2016 & 4126 & 3550 & 4010 & 5500 & 9250 & 13100 \\
\hline 2017 & 4710 & 4407 & 4106 & 6400 & 10500 & 13600 \\
\hline 2018 & 5850 & 6300 & 4500 & 7100 & 11600 & 14100 \\
\hline 2019 & 6100 & 5600 & 4650 & 10350 & 11950 & 14000 \\
\hline 2020 & 6225 & 5420 & 4840 & 10400 & 12150 & 14500 \\
\hline
\end{tabular}

Зважаючи на вищевказані обставини, які склалися у $\mid$ українцем було спожито 16,2 кг свинини за рік, що на 54\% галузі свинарства в Україні суттєво скоротився і обсяг споживання свинини. Так, в 2009 р. середньостатистичним менше мінімально рекомендованої норми споживання м'яса свиней на одну особу (рис. 5) [12, 16, 24-26].

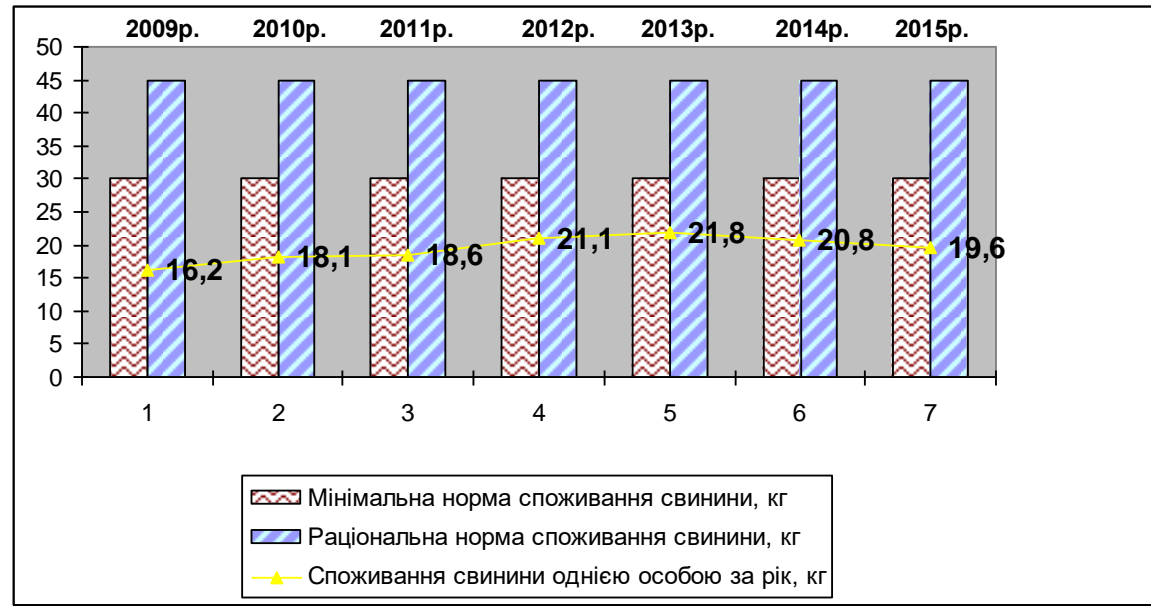

Puc. 5. Обсяг споживання свинини середньостатистичним українцем протягом 2009-2015 pp. (за даними Державної служби статистики України)

Як видно із рис. 5, споживання свинини українцями щорічно починає збільшувати оберти і вже на 2013 рік цей показник становить 21,8 кг за рік. Цей рівень споживання звичайно не $\epsilon$, навіть, мінімальною нормою споживання свинини, але він все ж таки є вищим, ніж споживання м'яса у 2009 року - на $34 \%$.

Чого не можна спостерігати, на жаль, протягом останніх двох років, де споживання м'яса свинини українцями безупинно знижується. Станом на 2015 рік цей показник на одного пересічного українця становить 19,6 кг, проти найвищого значення даного показнику, який був зафіксований у 2013 році. Таке негативне явище у суспільстві, перш за все, пов'язане із низкою причин: низькою платоспроможністю населення, низьким рівнем життя українців, зниженням аграріями виробництва м'яса у живій вазі, здорожчанням кормових засобів для годівлі свиней, скороченням на $28 \%$ імпорту м'яса тощо $[12,22]$.

За твердженням аналітиків Української аграрної асо- 
ціації (УАА), вивчивши внутрішню структуру ринку м'яса і з'ясувавши, скільки ж кілограмів м'яса на рік (і яких саме видів) споживає у середньому кожен українець, було помічено три цікаві тенденції. Перша - кількість споживання м'яса на рік одним українцем за 2017-2020 рр. майже не змінилась і незначно коливається: 2017-й р. - 48,98 кг $(4,08$ кг на місяць), 2018-й р. - 48,45 кг (відповідно - 4,04 кг), 2019й р. $-46,72$ кг (3,8 кг на місяць), 2020-й р. - 44,25 кг (3,2 кг на місяць).

Друга - загальна структура річного споживання теж стабільна, у ній домінує частка м'яса птиці. Саме вона становить половину раціону пересічних українців і її частка зростає: 2017-й р. - 24,34 кг на одну особу (49,7\% всього спожитого за рік), 2018-й р. - 25,15 кг (51,9\%), 2019-й р. 26,14 кг (55,9\%), 2020-й р. - 27,1 кг (61,2\%).

Третя - трійка видів м'яса зі щорічного раціону українців залишається останні роки практично незмінною. Окрім м'яса птиці до неї входять: 2-ге місце - свинина: 2017-й р. 13,8 кг (6,76\%), 2018-й р. - 12,6 кг (6,10\%), 2019-й р. - 13 кг (1,97\%), 2020-й р. - 10,9 кг (2,43\%); 3-тє місце - яловичина: 2017-й р. - 3,09 кг (6,3\%), 2018-й р. - 5,4 кг (2,62\%), 2019й р. $-4,8$ кг $(0,73 \%), 2020$-й р. - 3,6 кг $(0,81 \%)[4,5,12,22-$ 28], (табл. 3).

Динаміка річного обсягу споживання м'яса пересічним українцем, кг

\begin{tabular}{|l|c|c|c|c|}
\hline \multirow{2}{*}{ Вид м'яса } & \multicolumn{5}{c|}{ Рік } \\
\cline { 2 - 5 } & 2017 & 2018 & 2019 & 2020 \\
\hline М'ясо птиці, кг & 24,34 & 25,15 & 26,14 & 27,1 \\
\hline Свинина, кг & 13,8 & 12,6 & 13 & 10,9 \\
\hline Яловичина, кг & 3,09 & 5,4 & 4,8 & 3,6 \\
\hline М'ясо інших видів тварин, кг & 7,75 & 5,3 & 2,78 & 2,78 \\
\hline Загалом, кг & 48,98 & 48,45 & 46,72 & 44,25 \\
\hline
\end{tabular}

Зазначена інформація свідчить, що обсяги імпорту свинини у останні роки суттєво впали без зростання обсягів експорту, що викликано катастрофрічним падінням свинопоголів'я (понад $23 \%$ за 5 років) та неефективними заходами щодо запобігання поширенню АЧС. Однак, попит на свинину в Україні традиційно високий, а це призводить до подальшого росту цін на таку продукцію, що, в свою чергу, разом із відносно недовгим циклом виробництва стимулює виробників до нарощування темпів виробництва свинини.

Нині в структурі вітчизняної пропозиції значну частку займає продукція іноземного виробництва, обсяги якої почали стрімко збільшуватися з 2009 року (рис. 6). Однак, якість продукції, що ввозиться на територію нашої країни є досить низькою $[6,16,18,22,28]$.

За останні роки склад основних країн-імпортерів не змінився. Так, з 2014 року Німеччина збільшила свою пито- му вагу в імпорті свинини до України, а США і Бразилія поступилися своїми позиціями. Найбільших втрат зазнала Бразилія: вартісний обсяг поставок із цієї країни скоротився всемеро (для порівняння, вартість контракту на імпорт однієї тони свинини із Бразилії у 2012 році становила 2019 доларів США). Наразі основними постачальниками імпортованої свинини в Україну є: Польща - на 17,74 млн доларів (42,39\%); Німеччина - на 7,27 млн доларів (17,38\%); Нідерланди - на 5,65 млн доларів (13,51\%); інші країни світу - на 11,18 млн доларів $(26,72 \%)$ [12, 22, 30].

Як підтверджують дані (рис. 6), загальний обсяг імпорту свинини у 2014 році зменшився у п'ятеро, а у 2015 році - всемеро. В період з 2016 по 2017 рр. об'єм імпорту свинини збільшився до 304 тис. тон, а далі до 2020 року коливався в межах 219-251 тис. тон. Проте, Україна нарощує обсяги щодо експортування свинини.

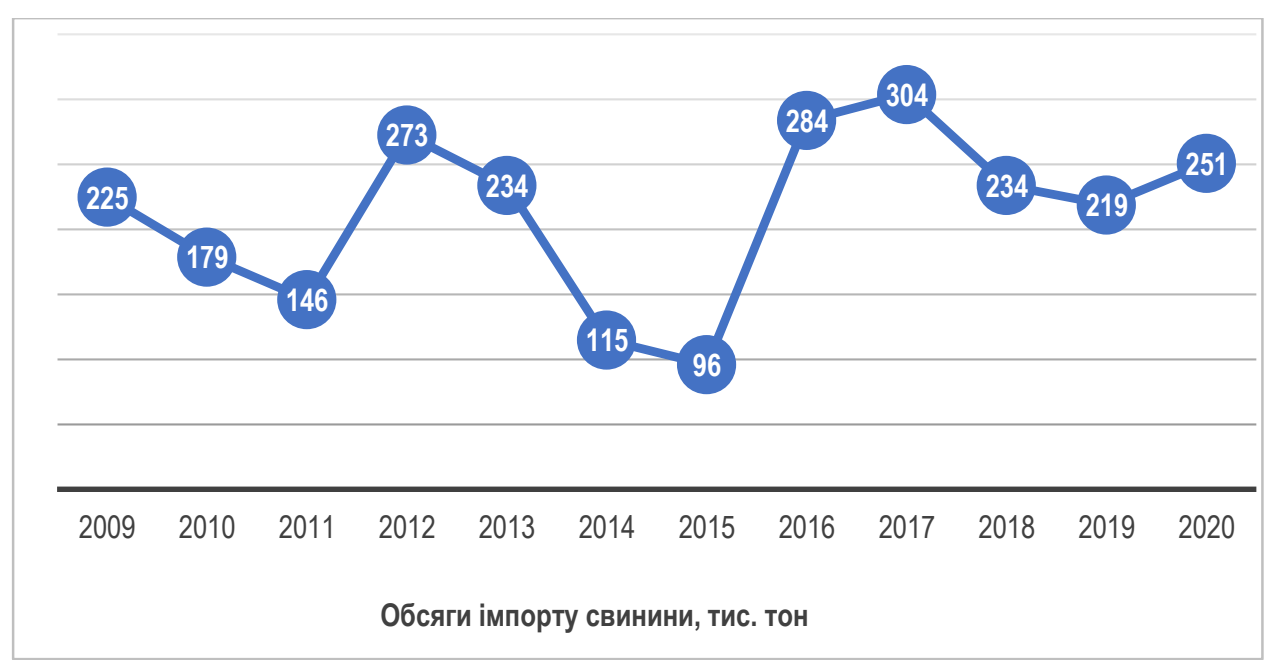

Puc. 6. Динаміка обсягів імпорту свинини в Україні (2009-2020 рр.)

В цьому плані вагоме місце відводиться провідним виробникам свинини в Україні: ПрАТ «АПК-ІНВЕСТ» (286339 загальне поголів'я свиней, 24702 голів маточного поголів'я, 57931 реалізовано свиней на забій у живій вазі), СП ТОВ «Нива Переяславщини» (221813 загальне поголів'я свиней,
14887 голів маточного поголів'я, 38575 реалізовано свиней на забій у живій вазі), ТзОВ «ґудвеллі Україна» (187905 загальне поголів'я свиней, 14095 голів маточного поголів'я, 37159 реалізовано свиней на забій у живій вазі), ТОВ «НВП Глобинський свинокомплекс» (154300 загальне поголів'я 
свиней, 12500 голів маточного поголів'я, 34000 реалізовано свиней на забій у живій вазі), ПАП «Агропродсервіс» (67500 загальне поголів'я свиней, 8800 голів маточного поголів'я, 18768 реалізовано свиней на забій у живій вазі).

Отже, перспективами розвитку галузі свинарства, на нашу думку, є: 1. Збільшення кількості поголів'я свиней в усіх категорій господарств країни до 11678,9 тис. голів; 2. Зниження конверсії корму до 2,5-3,2 кг, зниження віку забою тварин до 165-170 днів; 3. Отримання від свиноматки за рік 25-28 «ділових» поросят; 4. Збереження локальних вітчизняних порід.

Для реалізації даних перспектив слід вирішати наступні задачі: здійснити структурну перебудову галузі свинарства з пріоритетом розвитку промислового свинарства у сільськогосподарських підприємствах; провести системну технологічну модернізацію виробництва продукції свинарства, забезпечивши пріоритет інтенсивним та ресурсозберігаючим технологіям виробництва м'яса з конкурентними якісними та кількісними параметрами; виконати систему технічних перетворень в галузі свинарства за системами утримання, годівлі, роздачі кормів, мікроклімату, видалення та утилізації гною із можливістю автоматизації виробничих свинооб'єктів; забезпечити формування в країні маточного поголів'я свиней на базі кращих світових та вітчизняних генотипів; забезпечити захист вітчизняних виробників свинини на ринку продукції, провівши ефективну політику регулювання цін на ринку свинини; сформувати національні стандарти і нормативну базу на свинопродукцію, яка буде гармонійною зі світовими нормами; провести модернізацію зернової галузі сільського господарства; розробити і забезпечити програму розвитку вітчизняної науки і технології виробництва продукції свинарства та інноваційних проектів модернізації галузі на базі нових вітчизняних проектно-консалтингових і технопаркових структур; забезпечити модернізацію системи підготовки і перепідготовки кадрів для галузі свинарства.

Висновки і перспективи подальших досліджень. Для забезпечення прибутковості ведення свинарства в Україні необхідно здійснювати державні інтервенції ринку продукції свинарства. Це дасть можливість забезпечити продовольчу безпеку в державі, гарантувати виробникам мінімальні ціни на м'ясну продукцію, підвищувати їх економічні інтереси та стимули, наситити внутрішній ринок свининою в повній мірі, виходячи з науково обґрунтованих норм споживання м'яса в розрахунку на одну особу. Також, доцільно було $б$ регулярно надавати кредитну підтримку (кредитну субсидію) виробникам тваринницької продукції, яка може бути направлена на модернізацію виробництва для комплексного застосування інтенсивних технологій, а це, в свою чергу, впливатиме на конкурентоспроможність продукції.

Отже, підсумовуючи вищевикладене, акцентуємо увагу на те, що на сучасному етапі в Україні ставиться завдання радикально відродити галузь свинарства та перевести її на індустріальну технологію, а також добитися того, щоб вона могла давати дешеву, високоякісну та конкурентоспроможну продукцію. Для цього наша країна має необхідний племінний генофонд та племінну базу свиней, володіє родючими землями для формування відповідної кормової бази, а також висококваліфікованим потенціалом науковців і виробничників для раціонального ведення галузі свинарства. Перспективи подальших досліджень полягають у вивченні напрямів розвитку галузі свинарства в умовах індустріалізації технологічних процесів виробництва та реалізації продукції свинарства.

Подяка. Робота виконана в рамках держбюджетної тематики Міністерства освіти і науки України (номер державної реєстрації 0119U001042).

\section{Список використаної літератури:}

1. Аграрний сектор економіки України (стан і перспективи розвитку) / [Присяжнюк М. В., Зубець М. В., Саблук П. Т. та ін.] ; за ред. М. В. Присяжнюка, М. В. Зубця, П. Т. Саблука, В. Я. Месель-Веселяка, М. М. Федорова. К. : ННЦ IAЕ, 2011. $1008 \mathrm{c}$.

2. Аналіз і прогноз кон'юнктури світових ринків продукції тваринництва [Шпичак О. М., Лупенко Ю. О., Присяжнюк М. В. та ін.] ; за ред. О. М. Шпичака. К. : ННЦ ІАЕ, 2012. 250 с.

3. Аналіз поточної кон'юнктури і прогноз ринків тваринницької продукції в Україні та світі : монографрія / Шпичак О.М. та ін. Київ : ННЦ «IAE», 2015. 392 c.

4. Бабенко М. Свинарство 2021 - програти не можна виграти. [Електронний ресурс]. - Режим доступу: https://agronews.ua/news/stalo-vidomo-chomu-ukrainski-svynari-prohraiut-na-svitovomu-rynku/

5. Баланси та споживання основних продуктів харчування населенням України: стат. зб. / за ред. О. М. Прокопенко. Державна служба статистики України. К., 2018. 59 с.

6. Бондарська О. Глобальний ринок свинини. Прибуткове свинарство. 2015. № 4(28). С. 26-30.

7. Брик М. М. Сучасний стан та перспективи розвитку галузі тваринництва в Україні. Економічний аналіз, [S.I.], v. 28, п. 4, р. 331-337, гру. 2018. ISSN 2219-4649. [Електронний ресурс]. - Режим доступу: https://www.econa.org.ua/index.php/econa/article/view/1649/6565656727. doi:http://dx.doi.org/10.35774/econa2018.04.331.

8. Виклики та перспективи для свинарства. [Електронний ресурс]. - Режим доступу: https://kurkul.com/spetsproekty/479-vikliki-ta-perspektivi-dlya-svinarstva-reportaj-iz-forumu-svinoferma-maybutnogo

9. Гнатюк С.А. Результати і перспективи роботи господарств корпорації «Тваринпром». Вісник аграрної науки Причорномор'я. Миколаїв, 2015. Вип. 2(84). С. 15-22.

10. Грищенко Н.П. Розвиток свинарства в Україні. Науковий журнал «Тваринництво та технології харчових продуктів», [S.I.], n. 271, 2019. p. 16-23.

11. Демчак І. М. Моніторинг стану галузі тваринництва та ринків м'ясо-молочної продукції за січень-березень 2013 року в цифррах, граффіках, діаграмах / [І. М. Демчак, О. В. Сеннь, Д. М. Микитюк, О. Л. Чижевський]. К. : НДІ «Украгропрпомпродуктивність», 2013. 47 с.

12. Державна служба статистики України. [Електронний ресурс]. - Режим доступу: http://www.ukrstat.gov.ua/

13. Ібатуллін М. І. Організаційно-економічні засади реалізації продукції свинарства особистими селянськими госпо- 
дарствами. Вісник Сумського національного аграрного університету. 2016. № 2. С. 34-36.

14. Іванов С.С., Бородаєнко Ф.А., Топіха В.С., Лихач В.Я.. Ефективне виробництво свинини в умовах СВК «Агрофірма «Миг-Сервіс-Агро» // Вісник аграрної науки Причорномор'я. Миколаїв, 2015. Вип. 2 (84). Т. 2. С. 78-86.

15. Ковач Ю. Є., Ільїна Г. В. Ефективність свинарства в умовах сьогодення. Ефективність використання трудових і матеріальних ресурсів у сучасних умовах у свинарстві. Продуктивність агропромислового виробництва (економічні науки) : наук.-практ. 3б. Українського науково-дослідного інституту. К. : НДІ «Украгропромпродуктивність», 2011. № 19. С. 55-57.

16. Лихач В. Я. Обгрунтування, розробка та впровадження інтенсивно-технологічних рішень у свинарстві : монограффія. Миколаїв : МНАУ, 2016. 227 с.

17. Лоза А. А. Слагаемые успеха отечественного свиноводства // Тваринництво сьогодні, 2010. № 2. С. 18-20.

18. Особенности и перспективы развития рынка мяса и мясопродуктов. [Электронный ресурс]. - Режим доступа: //www.meat. com.ua/pol/? id=4

19. Особливості селекційно-технологічних рішень та організаційних форм у сучасному свинарстві / В. М. Волощук, І. В. Хатько, О. І. Підтереба та ін. Свинарство. Міжвід. темат. наук. зб. Полтава, 2012. Вип. 61. С. 3-8.

20. Рыбалко В. П. Проблемы производства свинины в странах СНГ // Свиноводство, 2010. № 7. С. 48-49.

21. Свинарство : монографія / [В. М. Волощук, В. П. Рибалко, М. Д. Березовський та ін.]. К. : Аграрна наука, 2014. $587 \mathrm{c}$.

22. Технологічні інновації у свинарстві : монографія / В. Я. Лихач, А. В. Лихач. Київ : ФОП Ямчинський О.В., 2020. 290 с., 101 табл., 65 рис.

23. Технологія виробництва продукції свинарства : навчальний посібник / [В. С. Топіха, В. Я. Лихач, С. І. Луговий, Г. І. Калиниченко, О. А. Коваль, Р. О. Трибрат]. Миколаїв : МДАУ, 2012. 453 с.

24. Тучкова А. Українське свинарство: розвивати, не можна покинути [Електронний ресурс]. - Режим доступу: http://pigua.info/uk/pigmarket/88/

25. Украинци потребляют сейчас в пять раз меньше мяса, чем при СССР. [Электронный ресурс]. - Режим доступа: http://www.20minut.ua/news/71619

26. Україна посідає 85-е місце в світі за споживанням м'яса на душу населення. [Електронний ресурс]. - Режим доступу: http://shuvar.com/index.php?mod=news\&cmd=details\&id=620

27. Україна у 2014 році наростила виробництво всієї продукції тваринництва - Держстат [Електронний ресурс]. Режим доступу: http: // ua.korrespondent.net/ business/economics/3318808

28. Шпичак О. М., Боднар О. В., Пашко С. О. Цінова ситуація на ринках продукції тваринництва в Україні. Київ : ННЦ «IAE», 2017. $52 \mathrm{c}$.

29. Шуст О. А. Економічні засади виробництва та реалізації продукції свинарства в сільськогосподарських підприємствах. Сталий розвиток економіки. 2011. №1(4). С. 276-280.

30. Management of innovative technologies creation of bio-products: monograph / V. Lykhach, A. Lykhach, M. Duczmal, M. Janicki, M. Ohiienko, A. Obozna, O. Kucher, R. Faustov. Opole-Kyiv, 2020. 223 p. 85 tab. Fig. 14.

\section{References:}

1. Ahrarnyi sektor ekonomiky Ukrainy (stan i perspektyvy rozvytku) [Agrarian sector of the economy of Ukraine (state and prospects of development)] / [Prysiazhniuk, M. V., Zubets, M. V., Sabluk, P. T. ta in.]; za red. M. V. Prysiazhniuka, M. V. Zubtsia, P. T. Sabluka, V. Ya. Mesel-Veseliaka, M. M. Fedorova. K. : NNC «IAE», 2011. 1008 p.

2. Analiz i prohnoz koniunktury svitovykh rynkiv produktsii tvarynnytstva [Analysis and forecast of world livestock markets] / [Shpychak, O. M., Lupenko, Y. O., Prysiazhniuk, M. V. at al]; za red. O. M. Shpychaka. K. : NNC «IAE», 2012. 250 p.

3. Analiz potochnoi koniunktury i prohnoz rynkiv tvarynnytskoi produktsii v Ukraini ta sviti : monohrafiia [Analysis of the current situation and forecast of livestock markets in Ukraine and the world: monograph] / Shpychak, O.M. at al. K. : NNC «IAE», 2015. 392 p. (in Ukrainian).

4. Babenko M. Svynarstvo 2021 - prohraty ne mozhna vyhraty [Pig breeding 2021 - you can't win to lose]. [Elektronnyi resurs]. - Rezhym dostupu: https://agronews.ua/news/stalo-vidomo-chomu-ukrainski-svynari-prohraiut-na-svitovomu-rynku/

5. Balansy ta spozhyvannia osnovnykh produktiv kharchuvannia naselenniam Ukrainy: stat. zb. [Balances and consumption of basic foodstuffs by the population of Ukraine: statistical collection] / za red. O. M. Prokopenko. Derzhavna sluzhba statystyky Ukrainy. K., 2018. 59 p.

6. Bondarska O. Hlobalnyi rynok svynyny [Global pork market]. Prybutkove svynarstvo. 2015. №4(28). P. 26-30.

7. Bryk M. M. Suchasnyi stan ta perspektyvy rozvytku haluzi tvarynnytstva v Ukraini. Ekonomichnyi analiz, [S.I.], v. 28, n. 4, p. 331-337, hru. 2018. ISSN 2219-4649 [Current state and prospects of livestock development in Ukraine. Economic analysis]. [Elektronnyi resurs]. - Rezhym dostupu: https://www.econa.org.ua/index.php/econa/article/view/1649/6565656727. doi:http://dx.doi.org/10.35774/econa2018.04.331.

8. Vyklyky ta perspektyvy dlia svynarstva [Challenges and prospects for pig breeding]. [Elektronnyi resurs]. - Rezhym dostupu: https://kurkul.com/spetsproekty/479-vikliki-ta-perspektivi-dlya-svinarstva-reportaj-iz-forumu-svinoferma-maybutnogo.

9. Hnatiuk S. A. Rezultaty i perspektyvy roboty hospodarstv korporatsii «Tvarynprom» [Results and prospects of work of farms of corporation «Tvarinprom»]. Visnyk ahrarnoi nauky Prychornomoria. Mykolaiv, 2015. V. 2(84). P. 15-22.

10. Hryshchenko N.P. Rozvytok svynarstva v Ukraini [Development of pig breeding in Ukraine]. Naukovyi zhurnal "Tvarynnytstvo ta tekhnolohii kharchovykh produktiv», [S.I.], n. 271, 2019. P. 16-23.

11. Demchak I. M. Monitorynh stanu haluzi tvarynnytstva ta rynkiv miaso-molochnoi produktsii za sichen-berezen 2013 roku v 
tsyfrakh, hrafikakh, diahramakh [Monitoring of the production of meat and dairy products for the current year 2013 in numbers, graphs, diagrams] / [I. M. Demchak, O. V. Senn, D. M. Mykytiuk, O. L. Chyzhevskyi]. K. : NDI «Ukrahroprpomproduktyvnist», 2013. 47 p.

12. Derzhavna sluzhba statystyky Ukrainy [State Statistics Service of Ukraine]. [Elektronnyi resurs]. - Rezhym dostupu: http://www.ukrstat.gov.ua/

13. Ibatullin M. I. Orhanizatsiino-ekonomichni zasady realizatsii produktsii svynarstva osobystymy selianskymy hospodarstvamy [Organizational and economic principles of sale of pig products by private farms]. Visnyk Sumskoho natsionalnoho ahrarnoho universytetu. 2016. № 2. P. 34-36

14. Ivanov, S. S., Borodaenko, F. A., Topikha, V. S., Lykhach, V. Ya., 2015. Efektyvne vyrobnytstvo svynyny v umovakh SVK «Agrofirma «Mig-Servis-Agro» [Effective production of pork in the conditions of Agro Firm «Mig-Service-Agro»]. Visnyk ahrarnoi nauky Prychornomoria. Mykolaiv. V. 2 (84). T. 2. P. 78-86.

15. Kovach, Y. Y., llina, H. V. Efektyvnist svynarstva v umovakh sohodennia. Efektyvnist vykorystannia trudovykh i materialnykh resursiv u suchasnykh umovakh u svynarstvi. [The efficiency of pig breeding in today's conditions. Efficiency of use of labor and material resources in modern conditions in pig breeding] Produktyvnist ahropromyslovoho vyrobnytstva (ekonomichni nauky) : nauk.-prakt. zb. Ukrainskoho naukovo-doslidnoho instytutu. K. : NDI «Ukrahropromproduktyvnist», 2011. № 19. P. 55-57.

16. Lykhach, V. Ya., 2016. Obgruntuvannia, rozrobka ta vprovadzhennia intensyvno-tekhnolohichnykh rishen u svynarstvi : monohrafiia [Substantiation, development and implementation of intensive technological solutions in pig production: monograph]. Mykolaiv : MNAU. 227 p.

17. Loza, A. A., 2010. Slahaembe uspekha otechestvennoho svynovodstva [Summaries of the success of domestic pig production]. Tvarynnytstvo sohodni. № 2. P. 18-20.

18. Osobennosty y perspektyvы razvytyia rыnka miasa y miasoproduktov [[Features and prospects of development of the market of meat and meat products]. [Эlektronnbii resurs]. - Rezhym dostupa: //www.meat. com.ua/pol/? id=4.

19. Osoblyvosti selektsiino-tekhnolohichnykh rishen ta orhanizatsiinykh form u suchasnomu svynarstvi [Features of selection and technological solutions and organizational forms in modern pig breeding] / V. M. Voloshchuk, I. V. Khatko, O. I. Pidtereba ta in. Svynarstvo. Mizhvid. temat. nauk. zb. Poltava, 2012. V. 61. P. 3-8.

20. Rybalko, V. P., 2010. Problemy proyzvodstva svynyny v stranakh SNH [Problems of pork production in the CIS countries ]. Svynovodstvo. № 7. P. 48-49.

21.Svynarstvo : monohrafiia [Pig farming: a monograph] / [V. M. Voloshchuk, V. P. Rybalko, M. D. Berezovskyi ta in.]. K. : Ahrarna nauka, 2014. $587 \mathrm{p}$.

22. Tekhnolohichni innovatsii u svynarstvi : monohrafiia [Technological innovations in pig breeding: monograph] / V. Ya. Lykhach, A. V. Lykhach. Kyiv : FOP Yamchynskyi O.V., 2020. 290 s., 101 tabl., 65 rys.

23. Tekhnolohiia vyrobnytstva produktsii svynarstva : navchalnyi posibnyk [Technology of pig production: a textbook] / [V. S. Topikha, V. Ya. Lykhach, S. I. Luhovyi, H. I. Kalynychenko, O. A. Koval, R. O. Trybrat]. Mykolaiv : MDAU, 2012. 453 p.

24. Tuchkova A. Ukrainske svynarstvo: rozvyvaty, ne mozhna pokynuty [Ukrainian pig breeding: to develop, it is impossible to leave]. [Elektronnyi resurs]. - Rezhym dostupu: http://pigua.info/uk/pigmarket/88/

25. Ukrayntsy potrebliaiut seichas v piat raz menshe miasa, chem pry USSR [Ukrainians now consume five times less meat than in the USSR]. [Эlektronnыi resurs]. - Rezhym dostupa: http://www.20minut.ua/news/71619.

26. Ukraina posidaie 85-e mistse v sviti za spozhyvanniam miasa na dushu naselennia [Ukraine ranks 85 th in the world in terms of meat consumption per capita]. [Elektronnyi resurs]. - Rezhym dostupu: http://shuvar.com/index.php?mod=news\&cmd=details\&id=620

27. Ukraina u 2014 rotsi narostyla vyrobnytstvo vsiiei produktsii tvarynnytstva - Derzhstat [In 2014, Ukraine increased production of all livestock products - State Statistics Service]. [Elektronnyi resurs]. - Rezhym dostupu: http: // ua.korrespondent.net/ business/economics/3318808

28. Shpychak O. M., Bodnar O. V., Pashko S. O. Tsinova sytuatsiia na rynkakh produktsii tvarynnytstva v Ukraini [Price situation in the markets of livestock products in Ukraine]. Kyiv : NNC «IAE», 2017. 52 p.

29. Shust O. A. Ekonomichni zasady vyrobnytstva ta realizatsii produktsii svynarstva v silskohospodarskykh pidpryiemstvakh [Economic principles of production and sale of pig products in agricultural enterprises]. Stalyi rozvytok ekonomiky. 2011. №1(4). P. 276-280.

30. Management of innovative technologies creation of bio-products: monograph / V. Lykhach, A. Lykhach, M. Duczmal, M. Janicki, M. Ohiienko, A. Obozna, O. Kucher, R. Faustov. Opole-Kyiv, 2020. 223 p. 85 tab. Fig. 14.

Lykhach Vadym Yaroslavovych, Doctor of Agricultural Sciences, Associate Professor,

National University of Life and Environmental Sciences of Ukraine, (Ukraine Kiev)

Lykhach Anna Vasylivna, Doctor of Agricultural Sciences, Associate Professor,

National University of Life and Environmental Sciences of Ukraine, (Ukraine Kiev)

Faustov Rostyslav Viktorovych, graduate student of the Department of Technology of

Livestock Production, Nikolaev National Agrarian University (Ukraine Nikolaev)

Kucher Olena Oleksandrivna, PhD of Agricultural Sciences, Docent

Mykolayiv National University named after V.O. Sukhomlinsky (Ukraine Nikolaev)

Current state and development trends of domestic pig breeding

Pig farming is an important branch of the national economy, which provides the population with food, processing industry raw materials, as well as contributes to the creation of the necessary state reserves of livestock products, intensive use of land re- 
sources. However, the actual state of the industry today does not correspond to its potential and requires additional attention from the state, practitioners, scientists. Thus, the aim of the research was to assess the current state and identify trends in the development of domestic pig farming as a strategically important industry in the overall structure of agricultural production in Ukraine. The number of pigs in Ukraine from 2009 to 2020 varied in different ways, the main reasons for the significant reduction in the number of pigs in the country include: the disparity in prices for agricultural and industrial products; rising feed prices; the inability of most domestic producers to use the latest technologies for keeping and fattening pigs; liquidation of specialized pig farms (up to 300 sows); saturation of the domestic market with raw materials of foreign production; reduction of state support; complications of the epizootological situation (ASF); difficult economic situation of ordinary Ukrainians. During the analyzed years, the least pork was produced in 2020, where the main cause of this phenomenon was adverse weather conditions, global and national economic crisis caused by the mass pandemic of the coronavirus COVID-19. This indicator shows that more than 70\% of pork in Ukraine is produced extensively, in at the same time the number of pigs in the EU, Canada, Brazil, USA will be produced, and $70 \%$ more pork is produced. At the present stage in Ukraine the task is to radically revive the pig industry and transfer it to industrial technology, as well as to ensure that it can provide cheap, high quality and competitive products. To do this, our country has the necessary breeding gene pool and breeding base of pigs, has fertile land to form an appropriate feed base, as well as a highly qualified potential of scientists and producers for the rational management of the pig industry. Prospects for the development of the pig industry are: increasing the number of pigs in all categories of farms to 11,678.9 thousand; reducing feed conversion to 2.5-3.2 kg, reducing the age of slaughter of animals to 165-170 days; receiving from the sow for the year 25-28 «business» piglets; preservation of local domestic breeds.

Key words: pig breeding, livestock, breed, pork market, agricultural enterprises, households, demand, import, price situation.

Дата надходження до редакції: 08.01.2021 